transforming, and I attended my first two in 1998. Soon after that, I went on to found back at home the London Latin Circle, for the same purpose of providing a regular space for practising speaking Latin.

These were the beginnings of my own path to Latin fluency, a path I recommend. Inspired by the value of the Assimil course in my own progress, and wanting to help others benefit from it too, I further established the free on-line Schola Latína Európcea \& Úniversális (SLEU). At a slow or a fast pace, in two years or one respectively, it provides students with comments and explanations, exercises, tests, and real-time answers to queries from volunteer experts. Those who have no French, German or Italian can also follow the method with the SLEU in English or Spanish. Overall, working with the SLEU is much easier than trying to tackle the long and considerably dense Assimil method alone. People from all over the world have long been benefiting from the course (Avitus, 2008) and practically all current members of the London Latin Circle have completed it too. Their fluency bears witness to its success.

- Schola Latína Európæa \& Úniversális: http://avitus.alcuinus.net/schola_ latina/

My advice to those wanting to develop fluency speaking Latin is therefore: a) to find a copy of Desessard's Assimil book and audio, and to work through it with the aid of the Schola Latina Európcea \& Úniversális, b) to practise expressing your own thoughts and opinions, not someone else's, in written Latin, through the Grex Latiné Loquentium or even a personal diary, and c) to start attending spoken Latin gatherings, seminars, events and courses, for exposure and the necessary benefits of immersion.

I will now enlarge on this last point, providing information about the wonderful things that are being done in spoken Latin in the UK, and about the even larger number of options to experience speaking Latin throughout the world.

\section{Recent developments in the UK}

Although spoken Latin had been gathering some momentum for a number of decades in Europe and America
(Licoppe, 2014), the only stable space to exercise actual spoken Latin in the UK had long remained the monthly sessions of the London Latin Circle (http://www. circuluslatinuslondiniensis.co.uk/). These sessions, taking place in the context of an affable pub dinner, include social conversation and discussion of Latin literature passages. The London Latin Circle has always welcomed participants of any level of ability.

A remarkable change of tide in the last few years, however, has brought about a wider explosion of interest in spoken Latin finally spreading to schools and universities too. This surge has gained momentum thanks to a rapidly growing number of successful endeavours, largely so far from abroad, which people have either been experiencing in person or witnessing through social networks, and indeed also thanks to the daring initiatives of a few praiseworthy scholars and the committed interest of an ever more numerous body of students themselves eagerly asking for this form of training in the UK.

At Oxford, the so-called Oxford Latinitas Project has recently been created. Under the ægis of Regius Professor of Greek, Gregory Hutchinson, and supported by the committed dedication of a very active group of postgraduate organisers, around 30 students (last time I visited) are meeting up to four times a week every week to activate their Latin. Three groups working at different levels use the famous method developed by Hans H. Orberg under the title Lingua Latina per se illustrata. Those who wish to gather on a different day converse in Latin over lunch in a group open to all abilities. A further two groups read and discuss classical authors in the original at two different levels. The project also holds a study day once a month on a Saturday.

In London, where I am a Senior Teaching Fellow at the University College London's Centre for Languages \& International Education, there are also exciting initiatives to report. In 2017, the UCL Department of Greek \& Latin took on a pioneering initiative to run a Living Latin Workshop. This was filled to maximum capacity with 20 attendees from different backgrounds, and offered participants the opportunity to experience various pedagogical methods involving the active use of the Latin language for Latin language learning (https:/ / www.ucl. ac.uk/classics/newsletter/Newsletter2017).
It was a remarkable event, and a particularly vivid example of the department's commitment to innovation in teaching in line with the recent UCL Education Strategy 2016-21. Dr. Emily ChowKambitsch, who convened the UCL Living Latin Workshop, contacted me through the London Latin Circle. She was looking for a fluent speaker who could give a lecture on current active Latin resources, and who could also

demonstrate spoken Latin as a tool for teaching not only Latin language, but also Latin literature. After the success of this venture, some of the students who had helped organise the workshop that year wanted to continue to explore speaking Latin this year too, and I was requested again to come and facilitate their sessions. A group of around 15 students, and one other UCL lecturer, have therefore been regularly meeting once a week for the whole of the academic year for this purpose. We also use the textbook by Hans H. Ørberg, Lingua Latina per se illustrata.

I understand that there are similar initiatives emerging at other universities and schools too of which I know less, and we all look forward to hearing about them. Meanwhile I am really delighted to report on the remarkable number of Classics students at two of the top UK universities who are increasingly showing a proactive determination to develop spoken fluency in Latin.

The story does not end here though, because in another proof of commitment to innovation in Classics teaching, the UCL Summer School 2018 will now for the first time offer two academic modules taught entirely in Latin. The modules are assessed and award credit (15UG) but are also open to any interested applicants with a good passive knowledge of the language. The first module (2-20 Jul: https://www.ucl.ac.uk/prospectivestudents/study-abroad-ucl/summerschool/modules/latin-usage) will explore Latin usage and idiom through the works of Terence, Cicero and Virgil, illuminated by the writings of their Latin commentators, and by the most recent scholarship on the matter. It will also include some practical training in teaching Latin idiom, again through the medium of Latin. The second module (23 Jul to 10 Aug: https://www.ucl.ac.uk/prospectivestudents/study-abroad-ucl/summerschool/modules/latin-literature) will 
comprise an academic introduction to British literature written in Latin, and provide an overview of its periods and genres. It will dwell on detailed commentary and discussion of specific key texts (Monmouth, More, Francis Bacon), and further explore the rich cultural connection between Britain and the rest of Europe (e.g. epistolography between More and Erasmus). Once again the module will be delivered in Latin.

These two modules constitute a giant stride for spoken Latin in the United Kingdom. In an intensive regime of full Latin language immersion, they bring together ancient and modern scholarship to advance knowledge of two important areas: the genuine nuances of idiomatic usage in the Latin of the native period in classical Rome, and the often neglected and yet exuberant and momentous treasure of national British literature originally produced in the Latin language through the ages.

\section{The international dimension of speaking Latin}

As we have seen, the British Latinist has an increasing number of occasions to get involved in spoken Latin at home. This has to be celebrated, every local opportunity seized and all endeavours fostered. However, the larger provision is still to be found abroad. This is not a bad thing, for various reasons. It is not uncommon to suspect that communication in Latin is some kind of pretence which only works because we are all thinking of the same English words and expressions hiding beneath the amusing sounds. There is no better way to allay this suspicion than to start speaking Latin with native speakers of German or Polish, and realise that we indeed understand each other in Latin through Latin alone, and that there is no underlying common language that could explain the phenomenon. The Latin we have all been learning from our Cicero or our Seneca still communicates. This is in itself an experience of the vigour of the language worth going abroad for. But there is more. I am persuaded that living the international dimension of Latin is essential to understand the real cultural importance of this language. A Hungarian may admire Shakespeare, but will never think English is part of his national heritage. A Briton may like Schiller, but will never pretend that the German language has a significant presence in his national culture. However, a Briton is aware that Latin has an inextricable and pervasive part in his national history and is core to his cultural heritage. A German feels that Latin is intrinsic to his national culture too. A Hungarian considers Latin the very same way as well. It is a very powerful experience to meet Germans, French, Hungarians, Poles, and feel that we are communicating in a language, the only language, that we can all feel is really ours in the same way, a language that automatically immerses us all in a culture that we all feel is our own in the same way.

For some reason, although the British are known for their ease to travel around the world, I have had quite a hard time trying to persuade fellow British Latin speakers to go abroad to meet the wider international community we are a part of. I hope the readers of these lines will be encouraged to be a bit more adventurous.

When UK Latinists discuss institutions that promote speaking Latin, their hearts and thoughts often fly first to the USA. This is understandable, but it somewhat circumvents the experiences I was commending above that come from communing with Latin speakers of different mother tongues.

I am satisfied that good information has been gathered in the literature (Hunt, 2016; Lloyd, 2016), regarding the initiatives of Professor Terence Tunberg at the University of Kentucky (Institute for Latin Studies \& Conventiculum Latinum), as well as those of the incomparable Reginald Foster's disciples at the Paideia Institute, of Nancy

Llewellyn at the North American Institute of Living Latin Studies (SALVI), and of the amazing Justin Slocum Bailey at Indwelling Language. Information also circulates about the work of Jason Harris at University College Cork, in Ireland, and Christopher Rico at the Polis Institute, in Israel. The reader should easily be able to find much more on all of these wonderful endeavours through the internet, and I wholeheartedly commend experiencing each and every one of them.

As Tunberg points out in his online videos though, the breeding ground of all this was in continental Europe, where the initiatives still thrive, and which happens to be reachable by train. I would like to make sure in this article that we all remain alert to this too, and so reap the fruits of their decades of work in the area (Licoppe, 2014).

Two European endeavours stand out above the rest in their success and their practical achievement, the Académía Vívárium Novum, based near Rome (Italy), and the Cursus Æstívus Latínitátis Vívæ Matríténsis, held yearly in the summer in Madrid (Spain).

The Académía Vívárium Novum (https://vivariumnovum.net/) is based in a Renaissance villa next to ancient Tusculum, and currently holds the greatest reputation in the spoken Latin world, deservingly so on account of the level of fluency participants reach. It hosts male youths under 24 for free during the academic year (October to June), and has an extended summer school (four or eight weeks) open to all genders and ages. Many illustrative videos can be found on YouTube. Most of the students behind the recent flourishing of living Latin at Oxford have strong links with this academy.

The Cursus Æstivus Latinitatis Vivæ Matritensis (CÆLVM) is a now five-yearold initiative in Madrid (http://www. culturaclasica.com/?q=caelum) which readers of this journal should mark as uniquely specialising in teacher training for spoken Latin through intensive summer courses of one week. It attracts about 180 Latin teachers every summer. Some Spanish is used at the opening and closing of the course, but all other course activity takes place in Latin. A good sample video (more on YouTube) is this one from the 2014 event: https://www.youtube.com/watch?v= 2f5VpyFoznU\&index=2\&list=PL6PTtr PBAg9xuW8733IZ3IzYKIcQEVcmF

The Collegium Latinitatis (http:/ / www.collegiumlatinitatis.com/) is an initiative of a passionate group of Latin teachers from Valencia (Spain) closely involved in the CÆLVM. They are likewise intent on improving teaching standards of Latin at all levels of education. They teach Latin literature in Latin, and also organise guided visits in Latin of the Museo del Prado in Madrid (there are videos on YouTube).

The most veteran organisations however, which in many ways set the foundations for all of the aforementioned, and which are still active to various 
extents, and so worth exploring, are in Germany and Belgium.

The Societas Latina Saravipontana of the University of Saarland is the child of late Cælestis Eichenseer, one of the most influential spoken Latin advocates of his time. It still publishes the Latin periodical Vox Latina and organises two spoken Latin seminars per year (click on seminaria Latinitatis vivæ at: http://www.voxlatina. uni-saarland.de/).

The Septimanæ Latinæ Europææ, now very popular and attracting a younger crowd of school and university students, also has two spoken Latin seminars each year, at Amöneburg in Hessen and Freising near Munich (http:/ /www. septimanalatina.org/).

The Latinitati Vivæ Provehendæ Associatio (LVPA) also organised immersion seminars, often in Eastern Europe (mostly Poland, although I once attended a wonderful one in Serbia), but I am uncertain about its current activities (http://www.lvpa.de/).

A now independent scion of the above is the Schola Æstiva Posnaniensis, which organises summer courses in Poland (https://scholaaestivaposnaniensis. wordpress.com/).

In Brussels, the long-standing Fundatio Melissa (http://www. fundatiomelissa.org/) hosts a Circulus Latinus and publishes the Latin periodical Melissa. Also in Belgium, the Schola Nova (watch the video at: http://www. scholanova.be/) is a private school that offers a strongly Græco-Latin curriculum with a living approach.

In the Netherlands, the Athenæum Illustre (http://www.athenaeumillustre. org/) has organised since 2012 many spoken Latin conferences, with activities in Amsterdam and other cities like Leiden; although, again, I am unsure about its current situation (many magnificent videos on You'Tube).

In Italy, the Schola Latina (http:/ / www.scholalatina.it/) is run by a number of previous partners of «Vívárium Novum» who have returned to Montella, where it all started. They also offer summer courses.

This international network of initiatives finds some coordination through the Académía Latínitátí Fovendæ (http://www.academialatinitatifovendae. org/). One of its greatest contributions is the scholarly conference it organises fully in Latin every four years (the latest one took place in Kentucky 27-31/7/2017). Its website used to have a section aimed at gathering information on all current living Latin initiatives, but they seem to be currently unable to offer such a crucially needed service. The academy has suffered many vicissitudes in its long history (Licoppe, 2014) and needs our involvement in order to be able to provide a cohesive and effective centre for speaking Latin endeavours at an international level.

A good way to obtain further information and support for speaking Latin is through the many Latin Circles that spread from Seattle to Hong Kong. Their websites (not all of them active) can be found listed in several places, and for instance here: https://www.google.com/ maps/d/viewer?mid=1IErsi89dopBy 9tPtiW2h12stDWs\&hl=en_US\&ll=8.800 $841462142246 \% 2 \mathrm{C} 133.480009 \& z=1$

Of course, even more information than this can be found through Google, and the scores of spoken Latin videos on You'Tube.

\section{Some notes on Latin school teaching}

Many good textbooks for teaching Latin have been published and are in use in this country. A number of recent ones have included conversational elements, some dialogue and a grammatical progression inspired by the advances in pedagogy made in the vernaculars. Examples of this go from the charming Minimus to the Cambridge Latin Course. Based on progressive reading, Reading Latin also comes to mind.

English being a global language, all of these methods are well known abroad, and have received praise. However, the method currently most widely and almost unanimously used internationally, both in Europe and in America, by all those interested in spoken Latin is the following:

- Hans H. Orberg, Lingua Latina per se illustrata, Hauniæ apud Museum Tusculanum 1991 [1981] https:// lingualatina.dk/wp/

This method teaches classical Latin grammar and the 3000 words most frequently found in the classical texts in a way that develops the linguistic instincts conducive to fluency. It is also the method of choice for the aforementioned speaking Latin initiatives of Oxford and London. The enhanced version produced by the Académía Vívárium Novum is supported by a tremendous wealth of resources: https://vivariumnovum.it/ catalogo/latino/corso-base

Orberg recorded the text of his method himself with very good pronunciation, despite rather fast diction, probably in an attempt to fit as much as possible onto every tape! Now iTunes has audio files of all of this, most of them free: https://itunes.apple.com/us/ album/familia-romana-latine-audio/ 528790763

Ørberg's method is somewhat similar to the graded reading approach of Reading Latin, but is completely self-explanatory in Latin, and so requires no use of any vernacular at all.

Lingua Latina per se illustrata does not refer to any modern contexts. In case of any specific interest in that direction, a good option, among a few others, would be Robert Maier et al., Piper Salve, Cursus Viva Latinitatis, Recanati, ELI s.r.l., 1998. This was produced by the organisers of the Septimanæ Latinæ Europæx mentioned above. The website says it is now out of print, but they have a new version: http://www.maierphil.de/ PiperSal/

Of course, a wonderful method is the one I also mentioned above, Desessard's Lingua Latina sine molestiá; but this is more for self-study, and not so practical for an actual face-to-face class.

There is certainly still much room for improvement in the area of textbooks to teach Latin in a communicative manner, and $I$ and others have this very much in mind. However, a word of warning is necessary. Sufficiently good methods for teaching classical languages this way were already produced, here in Britain of all places, by W.H.D. Rouse, and as early as the beginning of the 20th Century. A number of reasons can be adduced to explain why his attempts were not more successful. A crucial factor in the fate of those initial efforts would appear to have been that, at the time (Rouse was active at Perse 1902-1928), the number of initiatives and opportunities to master speaking Latin that we have today were not yet available. No matter how good a range of textbooks we have, if the 
teachers themselves cannot develop the required skills to exploit them, then the whole endeavour may not succeed. Now that Latin teachers are finally able to find abundant relevant training for the use of spoken Latin in the class, we have the opportunity to make communicative approaches flourish and deliver wider success.

Required training in this context is threefold. First of all, those aspiring to teach Latin in a living manner should be fluent in Latin themselves to be able to do so. Recommendations on ways to achieve this have already been provided.

Even being a completely native speaker of one's own language does not automatically make one a good language teacher of the same. Specific training is needed in the practical and effective teaching of that language. For a living mode (communicative approach), this kind of training is widely and often very conveniently available in the case of a global language like English. One of the best things that those aspiring to teach Latin as a spoken language could be advised to do is to get one of those TEFL/ TESOL courses under their belts, so that they can then transfer the strategies.

Finally, for the last five years there is now also a specialised teacher training course for spoken Latin, which should certainly be completed, even if it means crossing the Channel for sunny Spain: http://www.culturaclasica. $\mathrm{com} /$ ?q $=$ caelum

For the success of any attempts to promote living Latin teaching at school, three efforts therefore need to be undertaken:

- training teachers to speak Latin fluently and with complete practical confidence;

- training teachers in the effective and methodologically up-to-date teaching of languages, first their own, and then Latin; and

- producing textbooks which are purposefully adapted (in the type of activities, progression, etc.) to the needs of teaching Latin as a spoken language.

There is a lot of work to do, but also a lot of reason for hope. In 2005 I offered three spoken Latin sessions at the
Association for Latin Teaching (ARLT) Summer School, and did so again in 2017. The interest generated this second time was much keener. I intend to continue to cooperate with the ARLT to finally bring the old designs of founder W.H.D. Rouse to their practical fruition. I know for a fact that the will is there very much alive.

A much needed resource is a database of schools interested in this approach. Only a few days before I sat to write this I was approached by a teacher from a school in Italy trying to put together a KA1 Erasmus + project for a period of job shadowing of one or two teachers with a school equally interested in sharing experiences and comparing results obtained by teaching Latin with the communicative approach. I was unable to suggest any schools. I believe she eventually found what she wanted, but interested schools should have a means to be in touch with each other and know who else is trying this approach for sharing and support.

\section{Lecturing in Latin at university}

Teaching of the language has generally been seen as a pursuit for primary and secondary education contexts. However, more and more universities are now having to teach Latin language ab initio, so this is surely their concern too. Also, universities are where the future primary and secondary education teachers of Latin receive their training in the language. Effective Latin teaching is thus the responsibility and concern of university departments for these two crucial reasons.

I am further persuaded that speaking Latin is beneficial not only for language teaching, but for also the more specifically academic type of lecturing which deals with matters of literature, philosophy, history, and the like. I provided demonstrations of this type of teaching both at the UCL Living Latin Workshop and at the ARLT Summer School 2017 by delivering a lecture-seminar on intertextuality between Geoffrey of Monmouth and Virgil. The reason this works is that even students who can only communicate in Latin say to a $10 \%$ or $20 \%$ level of adroitness can actually understand spoken Latin to around 80\% or $90 \%$ if they have learnt the language before, because a lot of vocabulary and most of grammar is there stored in their memories, however passively. The attendants of the UCL Living Latin Workshop and at the ARLT Summer School 2017 were themselves surprised, though I was not, that they could follow my lecture without trouble, and they proved this with their relevant enquiries. During lectures delivered in Latin, students can thus receive the content knowledge imparted to them, and they further enrich their Latin enhancing their familiarity with the language itself.

There are unfortunately even fewer instances of lecturing in Latin than there are of language teaching through Latin. Two shining instances of the latter practice and its viability are exemplified in the delivery of a whole university programme in Latin at the University of Kentucky, and the programmes offered by the Polis Institute that are accredited by supporting universities in Italy and Spain.

Other than that, I know that some university lecturing in Latin was taking place in Germany, at least in three different universities, although I have struggled to find further evidence online. Certainly a world-famous classicist, Professor Michael von Albrecht, emeritus from Heidelberg (https://de.wikipedia. org/wiki/Michael_von_Albrecht), lectured in Latin, and remains one of the most active proponents of living Latin (many videos can be found in YouTube). The same can be said of Professor Wilfried Stroh, emeritus from Munich (https://de.wikipedia.org/wiki/Wilfried_ Stroh). I believe also Professor Axel Schönberger of Frankfurt lectures in Latin (https://www.uni-frankfurt. de/43605276/schoenberger).

In Spain, the University of Valencia is integrating lecturing in Latin too. Dr. Jorge Tárrega shares online his notes, bibliography, practical work, etc. for his courses on Sallust or Latin Morphology and Syntax, which he teaches entirely in Latin: http://jortaga.blogs.uv.es/

In this context it will be a pleasure for me to be able to contribute to the existing international provision the aforementioned two modules of the UCL Summer School 2018 which will be likewise delivered in Latin this summer. I hope to see many readers of this journal taking the chance to benefit (http:/ /www. ucl.ac.uk/prospective-students/studyabroad-ucl/summer-school). 


\section{Latin scholarship in Latin}

Beyond lecturing as part of a fullyfledged university course awarding credit, there are many international conferences where a number of public lectures are delivered in Latin. There is a greater abundance of this type of practice in the area of so-called 'Neo-Latin' studies, where scholars are perhaps more attuned to the perennial use of the language, although not only in that area. A couple of samples:

- On Jacobus Pontanus (Naples) [see 12:12 onwards]: https://www.youtube. $\mathrm{com} /$ watch?v $=8 \mathrm{YC} 8 \mathrm{dVMPtW} 4$

- On Thomas More and his Utopia (Amsterdam): https://www.youtube. com/watch?v = wQbsB4zp_d0

Many of these lectures are subsequently published in written form. In this context, and although no longer strictly speaking instances of spoken Latin, it is relevant to bring to mind the abundance of written scholarship published in Latin.

Participation in that scholarly debate necessitates a capacity to deal with the expression of new ideas in Latin which is very much akin to the capacity to speak fluent Latin. Classicists not trained in these skills cannot have ready access to much relevant scholarship, let alone produce it.

To put but one example, not just a Latinist, a Hellenist as well, specialising say in Homeric studies, should be able to contend with the extensive Latin treatises preceding the various volumes of Van der Valk's edition of Eustathius's commentary on the Iliad, Latin scholarship which is as recent as 1971. Students whose Latin only allows them to deal with classical texts for which there are bilingual editions and translations are excluded from much that is valuable.

I have long believed that a good research project would be the compilation of a comprehensive bibliography of all classical scholarship written in Latin in the contemporary period (from 1789), hopefully with a record/analysis of their citation rates by further (Latin and non-Latin using) scholarship.

While we wait for that, I will provide just a couple of examples from friends. I have in front of me an article on John
Owen written by Professor Jonathan G.F.

Powell, well-known editor of Cicero in the Bibliotheca Oxoniensis and for a time visitor of the London Latin Circle, where he demonstrated some of the most impeccable use of spoken Latin I have ever heard:

- Jonathan G.F. Powell. (1986). De Iohanne Audoeno, scriptore epigrammatum Cambrobritanno. In O. Dilke \& G. Townend (edd.), Acta omnium gentium ac nationum conventus sexti Latinis litteris linguaque fovendis: Britannia Latina. Kendaliæ, Wilson, pp. 130-134.

A Google search attests that this is quoted in at least three subsequent pieces of scholarship.

Scholarly periodicals like Mnemosyne, Hermes, Museum Helveticum, etc. also still publish articles in Latin from time to time. Again, just from friends (Polish and Spanish), a couple of examples can illustrate this:

\section{- Konrad M. Kokoszkiewicz (Mnemosyne} 58, 2005) A. Gellius Noctes Atticae 16.2.6: tamquam si te dicas adulterum negent (one among various others, the last one in Eranos 2010-11: http:// www.obta.uw.edu.pl/ $\sim$ draco/)

- Jorge Tárrega Garrido (Museum Helveticum 71, 2014) De hominum appellationibus in Ciceronis Epistulis ad Atticum: http:/ / www.e-periodica.ch/digbib/\%20 view?var $=$ true\&pid $=$ mhl001:2014:71::143

Although several universities still accept $\mathrm{PhD}$ theses in Latin (certainly von Albrecht's Heidelberg), I am not sure how often this option has been used (see above for the need of a compilation of scholarship in Latin). The jewel in the crown of this section must therefore be the whole 400 pages of a recent $\mathrm{PhD}$ thesis of 2015 defended at the University of Valencia:

- Ma Luisa Aguilar, Studia Varroniana: de titulis Varronis eorumque origine ac rationibus (resumen in Spanish, pp. I-XLIV, but body in Latin, pp. 1-389): http://roderic.uv.es/bitstream/ handle/10550/46825/tesis_mlaguilar. pdf? sequence $=1$ \&is Allowed $=y$

\section{Academic research on the practice and benefits of speaking Latin}

The last section of my contribution must go to the increasing academic activity written in the vernacular but about spoken Latin. This is highly recommended reading for those interested in this area beyond the necessary confines of the present article.

Most importantly, an absolutely pioneering $\mathrm{PhD}$ thesis entirely on this matter was defended only last year:

- Lloyd, Mair E. (2016). Living Latin: Exploring a Communicative Approach to Latin Teaching Through a Sociocultural Perspective on Language Learning: http:/ / oro.open.ac.uk/48886/

The editor of the Journal of Classics Teaching himself had just the year before published a crucial book on Latin teaching that devotes attention to the matter of active use of the language:

- Hunt, Steven. (2016). Starting to Teach Latin: https://www.amazon.co.uk/ Starting-Teach-Latin-Steven-Hunt/ dp/1472537912

Beyond that, highly informative are also the findings of a Census Latinus carried out in 2009, which were published just in 2017 too, with a new edition of the same expected to take place this year:

- Eduardo Engelsing, Census Latinus 2009: Goals, Data Collected, Importance, Perspectives: https:// muse.jhu.edu/article/658989/pdf

A not so off-the-press contribution of 2012 also makes for very interesting reading:

- Neil Coffee, Active Latin: Quo Tendimus?: http://www.academia. edu/3830834/Active_Latin_Quo_ Tendimus

\section{Conclusion}

I hope this article can stimulate and guide readers in trying out the experience of speaking Latin and exploring some of the many possible avenues now open in this direction. Students are certainly 
expressing more and more interest in this approach for the obvious reasons of greater immediacy and enhanced mastery in a language they genuinely love, and teachers and academics should be able to accompany and inspire them in this pursuit. I know for a fact that many long to do so.

I also hope that greater knowledge and awareness fosters more fluid communication among those interested in forwarding this approach and that they dare to support each other and increase the cohesion and inclusivity of the growing numbers of teachers and scholars interested in spoken Latin worldwide.

Vivat floreatque lingua Latina! aggfvavitus@yahoo.co.uk

A. Gratius Avitus is a Senior
Teaching Fellow at the UCL Centre
for Languages \& International
Education. His several decades of
experience encompass teaching of
Spanish, Latin, Greek and Sanskrit,
as well as Translation Skills, and
Classical Culture. He is a
passionate proponent of the spoken
use of the classical languages to
improve learning efficiency and
advance reading fluency among
students. He founded the London
Latin Circle and the free on-line
Schola Latína Európae $\&$
Úniversális, has contributed to the
development of conversational
Latin language methods, and is
actively involved in promoting the
communicative approach in Latin
at an international level.

Teaching Fellow at the UCL Centre

Education. His several decades of experience encompass teaching of Spanish, Latin, Greek and Sanskrit, as well as Translation Skills, and

Classical Culture. He is a passionate proponent of the spoken students. He founded the London Latin Circle and the free on-line Schola Latína Európaca \& Universális, has contributed to the development of conversational Latin language methods, and is at an international level.
A. Gratius Avitus is a Senio

\section{References}

Avitus, A.G. (2008). De vivá institutione Latiná per rete, Melissa 142 (2008) pp. 2-4.

Hunt, S. (2016). Starting to Teach Latin, London, Bloomsbury.

Licoppe, G. (2014). Academia Latinitati Fovenda, eius historia per motum Latinitatis viva considerata (1952-2012), Bruxellis, Melissa.

Lloyd, M. (2016). Living Latin: An Interview with Professor Terence Tunberg. Journal of Classics Teaching 34, pp. 44-48.

If you have enjoyed reading this, you might also like to read:

Carlon, J. (2011). Educating the Educators. JCT 22, pp. 13-14.

Carter, D. (2011). Hans Ørberg and his contribution to Latin pedagogy. JCT, 22, pp. 21-22.

King, J. (2011). Latin speaking camps. JCT, 22, p.12

Macdonald, S. (2011). Krashen and Second Language Acquisition theory - a

re-evaluation of how to teach classical

languages. JCT22, pp. 3-5.

Mahoney, A. (2011). A Communicative

Approach to Ancient Greek. JCT 22, pp. 14-16.

Parsons, D. (2009). Inspiration from Rouse. JCT17, pp. 5-6.

Peckett, C. (1992). The oral method. JACT

Review, 11, p.4-8.
Patrick, R. (2011). TPRS and Latin in the classroom. Experiences of a US Latin teacher. JCT 22, pp. 10-11.

Stray, C. (2011). Success and Failure: W.H.D Rouse and direct-method Classics teaching in Edwardian England. JCT22, pp. 5-7.

Tunberg, T. (2011). The use of Latin as a spoken language in the Humanist Age. JCT 22, pp. 8-9. 